\title{
TRANSFORMATIONAL LEADERSHIP PRACTICES IN COMMUNITY SCHOOL
}

\author{
Surya Prasad Adhikari ${ }^{1}$
}

\begin{abstract}
This paper aimed to explore the practice of educational transformational leadership practice in community schools. To complete this study, I used qualitative research design. I selected one head teacher as a key informant applying purposive sampling procedure. In addition to the head teacher, I collected data from student, parent, chairperson, ex-chairperson, educationist, ward chairperson, and legal person from the local body from audit report for the triangulation of data. I collected the data through the audio recording. I tried to make different "themes" from the data which is related to my research objective. Transformational leadership practices as a follower and the leader in community school is found collaborative and empowering own self and other too. As follower, the respondent was responsible to her parents, parents of students, management committee and head teacher. She was influenced by elder brother in her family and by school leader at school. As a transformational leadership, the roles and responsibilities were completed in time given by the authority. The school leader has given different authority and responsibility to the followers by providing position. Those followers have actively participated to complete their roles and support to the school leader. Management committee support and agree to the school leader basically focusing on meeting visionary agendas. Likewise, students, parents and community people also supported to the school leader's vision and mission. Student outcome and school effectiveness were also satisfactory by the school concern people.
\end{abstract}

Keywords: Head Teacher, Transformational Leadership, Purposive Sampling, Community School

1 Mr. Adhikari is a Lecturer, Central Department of Education, Kathmandu, TU 


\section{INTRODUCTION}

Schools are an academic and formal place for learning. There are teaching and non- teaching staff in a school. Non teaching staff facilitate for the teaching staff and help in making learning environment. Likewise, teaching staff are the teachers involved in teaching and learning of the students who are admitted in the schools for formal education. Teaching and non- teaching staffs of schools are daily monitored, supervised and evaluated by the authorized person known as "Head Teacher" (Ministry of Education 2028).

According to Davis, Darling, Hammond, Lapointe and Meyerson (2005) head teachers are the active leaders of schools. Head teachers are responsible for academic achievement and physical facilities provided to schools. They are accountable and responsible for schools. They have to focus on the educational progress of students and maintain a safe and homely environment (Pandey 2017).

Leaders of schools are always careful about academic achievements of their students. Leaders manage human, physical, economic and hardware resources. Effective leadership and capacity building are essential fundamentals in the transformation and redesign of the leaders. Schools are the institution for educational practice for the transformation of knowledge. Good leadership can achieve educational organizational goals with better achievement. The quality of leadership makes a significant difference to the improvement of schools and students outcome (Bush 2008). The concept of leadership and management is related to one another. There is a link between leadership and management; leadership is related with change, while management is seen as a maintenance activity (Cuban 1988 cited in Bush, 2008).

Transformational leadership creates the preferable environment for the leader and organization. It has been identified as the "favored style of leadership" (Marzano, Waters \& McNulty 2005). This leadership is collaborates and empowers the followers. Transformational leadership is mostly associated with vision, setting directions, restructuring and realigning the organization, developing staff and curriculum and involving with external community (Burns 1978, Bass 1995, Leithwood \& Jantiz 2005). Burns (1978) described transformational leadership modality as "potent" and characterized by "mutual stimulation and elevation that converts 
followers into leaders and may convert leaders into moral agents" (p. 4). Similarly, transformational leadership motivates, inspires, and elevates followers to embrace an ongoing effort or cause more significant and enduring an individual's needs or wants. Transformational leaders specially focus on more colleagues and followers than set up simple exchanges or agreements (Bass \& Riggio 2006). The leadership inspires the followers with challenge and persuasion, providing both meaning and understanding. Hein (2013) more described, transformational leaders are described as charismatic, enthusiastic, optimistic, passionate and sometimes visionary, giving them the ability to change long-held perceptions and beliefs.

Head teacher is always active in building human relation, creating quick decisions, making the favored environment, establishing the collaboration with society people, school management committee, parents teacher association, different NGOs and INGOs staffs, teaching and non teaching staffs, students and concern people of school. Leader is always visionary.

\section{OBJECTIVE}

The purpose of this study is to explore the practices of transformational leadership as a follower and visionary leadership in community schools.

\section{METHODOLOGY}

Post positivist philosophical paradigm was the method of this study. It employs a narrative research design. Narrative research design focuses on the study of a single person, gathering data through the collection of stories, reporting individual experiences, and discussing the meaning of those experiences for the individual (Creswell 2012). For the purpose of this study, one school of Hansapur (pseudonym) municipality was purposively selected. To elicit the required data and information, the tools lime in-depth interviews group discussion were done.

The participant in this study was a head teacher of Shree Secondary School (SSS) (pseudonym).

I conducted few numbers of narrative interviews with Shanta (pseudonym). A face-to-face interview was taken with Shanta and a few times accompanied by SMC chairman, parents, student, focusing on her experience. I tried to maintain the comfortable environment. I used a 


\section{TRANSFORMATIONAL LEADERSHIP PRACTICES IN COMMUNITY SCHOOL}

recording device to record the conversation with her followers and visionary experience, which included all the events, examples, and anecdotes associated with her home and school experiences. I collected rich narrative data from her which enabled me to explain the problems faced by the girls at home and as a follower and a leader in community schools. I was able to identify the range of problems with the previous girl's education.

Cross interviews were also taken from ex-chairman of SMC, chairman of SMC/social audit report, student, parent and representatives from local government; ward chairman, legal advisor from Hansapure Municipality (HM) (pseudonym) and educationist advisors of SSS. Initially, I transcribed the information taken from the narrative inquiry. Then I prepared some of the 'basic themes' from the data elicited form the recorded narrative and the diary and the records. From the commonalities of the basic themes, I categorized these basic themes and prepared 'organizing themes', then again I came to the 'global themes' from the organization themes (Stirling 2001).

\section{RESULTS AND DISCUSSION}

This paper discusses the transformational leadership role in a community school. To explore the exploration of the ways of transformational leadership in community school, I collected information from the head teacher and other people who participated in social audit report announcement of SSS. I visited the school several times to develop the personal rapport and make the respondent comfortable in exploring her ideas. Informally, I interacted with her regarding leadership. To maintain the authenticity, I managed a tape recorder to collect information with her consent. Data were collected until saturation of information.

The analysis was carried out through multiple readings and interpretations of the raw data, the inductive component (Khanal 2012). I tried to make different "themes" from the information or data related to my research objective. The transcripts were read several times to identify the actual themes and categories.

\section{Leader as a follower}

Each and every person may be influenced by parents, teachers, seniors, specialists, societies and many other situations. That becomes the best way to get success and enlighten of the life. Gautama Buddha was 
enlightened by seeing the old, ill, dead and sorrow man. He wanted to know why and how are these being faced in human life. These questions were raised in his mind, and he tried to find out the solutions of these problems. After a long meditation he got the solution.

Shanta's mother was illiterate but her father was literate. Their main occupation was agriculture. Besides agriculture, her father was engaged in carpentry and other members were engaged in flatten rice made machine "Chiura kutne mill". Oral language is, at a behavioral level, similar in illiterate and literate subjects (Castro-Caldas et al. 1998). People can talk and behave politely with other people. Similarly, her third elder brother Narayan (pseudonym) was the best motivator/aspirator that helped Shanta achieve enlighten. She could finally become a heroin or leader of SSS and society. "Leadership is the process, where by an individual influences a group of individuals to achieve common goals" (Northhouse 2013). The parents and neighbors of her society never accepted to educate daughters because daughters were the guest for them. They thought that daughters would go to the other's (husband) house. So, it was not necessary to provide education for them. Male child preference has existed since agrarian society. The role of son was important in farming. Young boys learned to do farm work with their fathers. Therefore, a large family with many sons was a sign of wealth and success (Miller 2010 as cited in Park 2011). Still, many Asian countries have a male child preference. It was believed that male children are the agents of sender of parents' soul to the heaven.

Since her third eldest brother didn't believe in these stuffs, he supported to send Shanta to school seeing her capacity. She was admitted SSS in class one and she worked hard. All of her family members including her father, mother, brothers and sister in-laws helped in her studies. Nobody expected house work from her. Shanta's habit was always accepted by all of them. She was obedient and accepted every requests and orders said by her family members just replying "Hass" every time. Our sister always accepted what we requested her to do but she never completed the assigned households as she remained busy for her studies most often. Due to her deep concentration in study, she passed SLC exam with the highest mark in the second division (59.9\%). She had a memory that her SLC result was published (2036 ashad 31), her brother named Naryan came to her and said "mero bahini le SLC second division ma pass garyo" (My sister have passed SLC in second division). He brought her in his shoulder and 


\section{TRANSFORMATIONAL LEADERSHIP PRACTICES IN COMMUNITY SCHOOL}

danced and repeated the same sentence again and again. He was the one who helped her for her study in the case of difficulties. Similarly, her family was oriented by him about education and life skills. That helped her for academic environment.

After SLC, she completed I. Sc. and B. Sc from Trichandra College. Similarly, she did M. Sc. and one year B. Ed. from the University Campus, Kirtipur. Her highest academic qualification was M. Phil. from the same University in Education Faculty T.U.

Her aim was to become a successful medical doctor. After the revolution in Nepal in 2038 B.S, her I. Sc. result could not be published in time. So, she kept waiting for the result. Suddenly she was informed by SSS principal for science teacher. She had leisure time. Physical and mental activity always supported her to be healthy. So, she agreed the principal's request to be a primary level teacher but she had an enough knowledge by which she could easily teach science in secondary level instead. She was the only female teacher of secondary level. After a month, lower secondary level post was empty and she was appointed in the same post.

By the support of her elder brother, she could be successful women and get many opportunities in her life. The members of her family made her a proper study environment in home. Principal of SSS provided the teaching job opportunity in her pioneer life. Due to all these reasons, she was one of the obedient followers which led her to become a leader.

\section{Leader as a visionary leadership}

As a researcher, I joint to a social audit program organized by SSS. Principal (Shanta) presented "social audit report of 2074" in date 2075/5/16. She reported it in five aspects; educational, physical, social, economic and other. At that time the participants and commentators also expressed their views in order to support her audit report as a visionary leader.

Saramila (pseudonym) was a parent of the one of the school's student and a member of social audit. She expressed her agreement on the report prepared and it was viewed as:

"I was highly satisfied with the school and its leadership because school achieved good result in SEE, physical construction was going on, academic social environment and 
overall development of school was acceptable. That was only possible only through the SSS leadership."

My observation was also the same as Sarmila addressed. Principal was connected with the every teachers, guest, participants and a short talk was done before starting the program. Recently, SEE result was published and all of the SEE students were passed. Academic building, hostel, canteen, toilet were under the construction for the betterment of academic environment of SSS. The relationship among teachers, students and leader of school made an academic climate to understand the extent to which they were related to each other and student outcomes (Gase et al. 2017). Good relation with stakeholder results good outcome of the students.

Sangam (pseudonym) was a representative of local government from Hansapur Municipality - HM (pseudonym of municipality) for the audit report program. He expressed that:

Social audit report must be held by the social organization. SSS was the first school in this term. Very few public organizations published the social audits. Head teacher of this school legitimatize the social audit and they are the first person of this municipality. So she was the thankful model and visionary leader.

Bennis and Nanus (1985) as cited in Martini, (2008) discussed the necessity of leaders developing a vision strategy. Sashkin (1988) as cited in Martini, (2008) identified five types of personal behavior that a visionary leader exercises: focusing attention, communicating personally, demonstrating trustworthiness, displaying respect, and taking risks. Only the visionary leaders can imagine the future of school.

Shanta expressed that, she did not have any experience of coming back from any agendas decision making from SMC, PTA and staff meetings related to school development. It is concluded that she presented academic, economic, social and physical agendas after research and the findings. It helped in decision making by the concern. Her decisions were made as after suggested by the concerned people in the process of collected information. Two heads are better than one has long been accepted (Robbins, Judge, and Sanghi 2009). Collective sources or information are more reliable and valid. 


\section{TRANSFORMATIONAL LEADERSHIP PRACTICES IN COMMUNITY SCHOOL}

Shyam (pseudonym) was a student of SSS and a representative of social audit. He explored:

I am standing in front of stakeholders of school as a represented of school's student and topper of grade eleven of SSS. That is only possible because of inspiration and motivation for me after the logical study, creativity and activated me by the school leadership.

From researcher observation, school leader was very close to the students and treated them by saying sons and daughters. Shanta always encouraged them to study and participate on extracurricular activities as students' expertise. That motivates students for exploring their capacities. Students were motivated to explore their capacities. The environment was made by the leadership of the school.

Hari (pseudonym), chairman of HM ward number fifteen (pseudonym) expressed that:

"I was totally unknown about; the community organization and institution must prepare a social audit. From the day he realized, he never recommended any organizations and institutions without social audit from his catchment area. He learnt this through the SS School's leader. The principal had invited him as a chair person of social audit program of SSS. He believed on the leader of that school. Whatever she will need recommendation from his word number fifteen, without any delay he will be provided any hands and recommendations or help for the school development. Her vision was appreciable and imitable. SSS was not booming because of the leader's vision.

I, being a researcher, separately talked to Hari, the chairman of HM word number fifteen about the SSS leader. He added more about his experience mentioning that he did not know about social audit, before that day. Leader's vision is the great for the achievement of school goals. So, he decided to monitor the social institutions and aware the social audits. His eyes opened because of SSS leader encouraged the social audit. The social bookkeeping and, more specifically about the value of social audit being conducted by school themselves (Gray et al. 1996). Social audit makes 
clear accounting mirrors to the concerned people of the schools. Chairman of school management committee, Suman (pseudonym) expressed;

This school was not only for social audit. SSS was first established in the northern belt (pseudonym) of Kathmandu valley when Rana ruled during 2004 B.S. Community people around the school had further visions. School Management Committee, Parents Teacher Association (PTA), teachers, students and mostly visionary leadership of the school are collaborating with each of the followers. Different aspects educational, physical, economic, social and other related activities were very clear and fair like a mirror. Now a day different buildings; hostel, canteen, girls toilet, academic building and recto feting in old academic building were under the construction by the help of World Bank. Each and every aspects of the school were sustainably developed for about 20 years.

Ministry of Education (MoE), Department of Education (DoE), HM, United Nation (UN), Non- Government Organizations (NGOs) and International Non- Government Organizations (INGOs) supported to the SSS because fairness and vision of principal. That school was selected as a model school by the Nepal government because of proper management of educational, physical, economic, social and other aspects.

One of the girl students 'Rina' (pseudonym) will be going to Canada (pseudo name of country). The LIT world club selected her by seeing how well she had written the story of her life. SMC ex chair- person stated that from above all our school leadership was seen the best leadership. Similarly, "Now a day, parents seem to be moving their children to the best school with a good studying environment". So, Parents had chosen SSS observing the outcome of the students. SSS had two education steams (general education Early Child Development (ECD) to 12 and vocational 9 - 12 class).

As a researcher, I visited SSS many times formally and informally. I talked with Suman (pseudonym) who was an ex-chairman of SMC. He has always appreciated the head teacher of SSS. However, Shanta could 
only be able to run successfully. Her vision, idea, motivation, collaboration, teaching style and decision making process were awesome. It contributed a lot to make SSS a model school. The work of leadership involves developing skills in dialogue, inquiry, reflection, collaboration, facilitation, good teaching, knowledge, skills and conflict resolution (Lambert 2011). The school leader is the main guideline of academic and extracurricular activities too.

Advisor of SSS and educationist, Hari (pseudonym) elaborated that:

Leader and followers always work hard for the betterment of the school. Community could evaluate either school's leaders or followers were doing well or not. The role of leadership was seen for the betterment of the school.

Informally, Hari expressed his views about the principle of SSS. He expressed that principal of SSS was a role model, social, academician, and a good researcher. According to his point of view, the head teacher didn't have any hesitations to ask any confusion about any aspect of school's development. Her confidence, collaboration, habit, behavior and vision of school were the property of the school. Schools are with a "sense of community" appear as an important institutional choice to the excessively bureaucratic public institutions that are increasingly common in American life (Bellah , Tipton, Swidler, and Sullivan; 1985 as cited in Bryk, Mar, and Driscoll, 1988). "The basic organizational features of and how they interacted to form a 'sense of community' remain to be articulated" (Bryk et al. 1988). Schools are academic institutions which addresses the dream of the community people. So, the community people are the watch guard, evaluator and supervisor of school.

Chairman of social audit report or chairman of SMC Arjun (pseudonym) added more;

He was very much glad that such people were living around SSS. School leader, SMC and community people were thankful to make SSS a model school. SSS was no less than any other reputed schools. He said that SSS deserved to be compared with St. Xaviers, Buddhanilakantha, Darbar School. SEE results were similar to reputed private boarding 
schools. School leader and teachers were thankful for making academic achievement. That was only possible because of visionary leadership. That was a model purposed school. So, for the complete model school; leader, teachers, SMC, PTA, community, local government should support and worked hard more than now. Present school leader collaborated with stakeholders. So, SSS was purpose as a model school.

As a researcher, I discussed with Arjun, the Chairman of social audit report. He further added that he got a chance to work with reputed schools head teacher or leader in Kathmandu as SMC chairperson. He also claimed that Shanta was the model and visionary head teacher among all of them.

From the above discussion, all of the participants closely supported to the leadership of SSS. They agreed with the visionary leadership of the leader of the school. The leadership style was best because of her leadership behavior educational, physical and student outcome. She had a clear vision after she got a support from community people, parents, PTA, SMC, advisors of the school, ex-student union and local government. With respect to all the supports she got, she could successfully be able to give this school a top position. She had also got a good supports from INGOs, NGOs, DoE, EDCU, UNDP, World Bank and many more.

Abrahm Maslow's Hierarchy need based theory is applicable in my study. According to this theory, once anyone's need is fulfilled, another arises. The needs keep on increasing unless there is the highest achievement of "self-actualization" (Robbins et al. 2009). In this study, leader is always active and well prepared for the vision and collaboration with followers. Leaders collaborate for the betterment of the model school with the other concerned person and an organization. As a leader, my participant always actively participated in each and every activity and encouraged the followers to participate to achieve the needs.

\section{CONCLUSION}

This study is based on the leader's education background and leadership style. Females worked really hard to get a good and proper education until last decades of 20th century. Transformation leaders have a concept about collaboration, sharing vision, setting directions, restructuring 
organization and developing staffs. They make a favored leadership style, empower the followers and also motivate, inspires to the followers for the improvement of the school. Transformative leadership converts followers into leaders and moral agents.

In conclusion, a qualified and experienced leader is found using modern transformation leadership. The school leader is found sharing the power and collaboration with the followers which make them more responsible and accountable in their duties. Gender is not hindering the leader. However, an academic quality and group mobilization capacity is the most for them. School has a physical, economic, academic and many other sectors for the better management. Leader internalizes that a single leader may not be able to complete the work on each and every sectors. So, as far as possible, leader empowers the followers to become the future leader by providing them different authorities and sharing vision with the followers and others for the cooperation of school improvement.

\section{REFERENCE}

Bass, B.M. (1995). Two decades of research and development in transformational leadership. European Journal of Work and Organizational Psychology, 8(9):3 2. doi. org/10.1080/135943299398410

Bass, B. M. \& Riggio, R.E. (2006). Transformational leadership (2nd ed.), London: Lawrence Erlbaum Associations.

Burns, J. M. (1978). Leadership. New York: Harper \& Row.

Bush, T. (2008). Leadership and management development in education. London: Sage Puplication Ltd.

Castro-Caldas, A., Petersson, K. M., Reis, A., Stone-Elander, S. \& Ingvar, M. (1998). The illiterate brain learning to read and write during childhood influences the functional organization of the adult brain. Brain, 12(1): 1053-1063. Oxford University Press.

Creswell, J. W. (2012). Educational research: planning, conducting, and evaluating quantitative and qualitative research (4thed.). Boston, MA: Pearson. 
Davis, S., Darling- Hammond, L., LaPointe, M.A. \& Meyerson, D. (2005). School leadership study: Preparing successful principals. Review of Research. Stanford, CA: Stanford University.

DeCenzo, D. A. \& Robbins, S. P. (2005). Fundamentals of human resource management. New Delhi: John Wiliey.

Gase, L.N., Gomez, L.M., Kuo, T., Glenn, B.A., Inkelas, M. \& Ponce, N.A. (2017). Relationships among student, staff, and administrative measures of school climate and student health and academic outcomes, Journal of school health. doi: org/10.1111/josh.12501

Gray, R. Owen, D. \& Carol, A. (1996). Accounting and accountability: Changes and challenges in corporate social and environmental reporting. London: Prentice Hall.

Hein, R. (2013). How to apply transformational leadership at your company. https://www.cio.com/article/2384791/careers-staffing/ how-to-apply-transformational-leadership-at-your-company.html

Khanal, P. (2012). Policy as practice of power: An analysis of the policy to decentralize school education in Nepal. PhD Thesis, Canterbury Christ Church University.

Lambert, L. (2011). What does leadership capacity really mean? Teacher leadership: A leader. New York: Peter Lang Publishing, Inc.

Leithwood, K. \& Jantzi, D. (2009). Transformational leadership: The essential of school leadership (2nd ed.). Las Anglese: SAGE.

Martini, P. H. (2008). Toward an Integrated Model of Visionary Leadership: A Multilevel Study. PhD Thesis, Regent University.

Marzano, R., Waters, T., \& McNulty, B.A. (2005). School leadership that works: From research to results. Alexandria, VA: Association for Supervision and Curriculum Development.

Ministry of Education (2028 B.S.). Education act 2028, Kathmandu: Ministry of Education.

Northhouse, P.G. (2013). Leadership: Theory and practice (6th ed.). London: SAGE Publication.

Pandey, I. (2017). Head teachers leadership for school improvement. An unpublished M.Phil. thesis, Faculty of education, Tribhuvan University. 
Park, S. (2011). Male child preference. World Cultures Research Paper. November 4.

Rayn, R.M. \& Deci, E.L. (2017). Self determination theory: Basic psychological needs in motivation, development and wellness, New York: The Gulford Press.

Robbin, S., Judge, T.A. \& Sanghi, S. (2009). Organizational behavior. Delhi: Pearson Prentice Hall.

Starlin, J.A. (2001). Qualitative research, thematic networks: an analytic tool for qualitative research, pp. 385-405. London: Sage publication. 